ISSN 0103-5150

Fisioter. Mov., Curitiba, v. 28, n. 2, p. 357-363, Apr./June 2015

Licenciado sob uma Licença Creative Commons DOI: http://dx.doi.org.10.1590/0103-5150.028.002.A016

\title{
Changes in muscle strength in elderly women after proprioceptive neuromuscular facilitation based training
}

\section{Alteração da força muscular em idosas após treinamento com facilitação neuromuscular proprioceptiva}

\author{
Edivã Bernardo da Silva ${ }^{[a]}$, Alessandro dos Santos Pin ${ }^{[a]}$, Manoel da Silva Filho ${ }^{[b] *}$ \\ [a] Universidade Federal do Amazonas (UFAM), Instituto de Saúde e Biotecnologia, Coari, AM, Brazil \\ ${ }^{[b]}$ Universidade Federal do Pará (UFPA), Instituto de Ciências Biológicas, Belém, PA, Brazil
}

\begin{abstract}
Introduction: Proprioceptive neuromuscular facilitation (PNF) can be used to improve the quality of life of both healthy and diseased subjects, including the elderly, who suffer muscular weakness due to aging, leading to an impairment in functional capacity. Objective: Verify the effectiveness of PNF as a tool for functional conditioning. Materials and methods: We evaluated a total of ten elderly women aged 60-70 years, clinically healthy and physically active. They had the force of motion of hip flexion with knee extension analyzed by an analog dynamometer. They were then randomly and equally divided into experimental (EG) and control group (CG). The GC was instructed to continue with their normal activities while the GE held 15 training sessions in the lower limb (LL) based on the diagonal D1 and D2. Finally, a new collection wrench the two groups
\end{abstract}

* EBS: Grad., e-mail: edivasilva@bol.com.br ASP: PhD, e-mail: keysersoze@bol.com.br MSF: PhD, e-mail: manoel@ufpa.br 
was performed and the data compared. Results: There was a significant increase in the average strength of GE, on the order of $31 \%(p<0.01)$. The GC also had increased strength, but not significant $(p>0.05)$. Discussion: The results confirm that the FNP through initial work of readjustment and proprioceptive neuromuscular activation, and after that, conditioning of the muscle fibers (mainly resistive) is capable of amplifying the force developed by the muscle. Conclusion: The PNF was effective as training to gain muscle strength, should be better analyzed as a tool fitness, not to cause health risks, have low cost and easy application.

Keywords: Muscle strength. Resistance training. Exercise therapy.

\section{Resumo}

Introdução: A facilitação neuromuscular proprioceptiva (FNP) pode ser utilizada na melhora da qualidade de vida de pessoas saudáveis ou não, incluindo os idosos, que sofrem redução da força muscular decorrente do envelhecimento, levando a um comprometimento de sua capacidade funcional. Objetivo: Verificar a eficácia da FNP como ferramenta de condicionamento. Materiais e métodos: Participaram dez mulheres idosas com idade entre 60 e 70 anos, voluntárias, fisicamente ativas e clinicamente saudáveis. Elas tiveram a força do movimento de flexão de quadril com extensão de joelho analisada por meio de dinamômetro analógico e, após isso, foram divididas aleatoriamente e igualmente em grupo experimental (GE) e grupo controle (GC). O GC foi orientado a continuar com suas atividades normais, enquanto o GE realizou 15 sessões de treinamento no membro inferior (MI) baseado nas diagonais D1 e D2. Ao final, nova coleta dinamométrica dos dois grupos foi realizada e os dados comparados. Resultados: Encontrou-se aumento significativo na média de força do GE, na ordem de 31\% $(p<0,01)$. O GC também obteve aumento de força, porém não significativo ( $p>0,05)$. Discussão: Os resultados confirmam que a FNP - por meio de trabalho inicial de readequação proprioceptiva e de ativação neuromuscular e, após isso, condicionamento das fibras musculares (em especial resistivas) - é capaz de ampliar a força desenvolvida pelo músculo. Conclusão: A FNP mostrou-se eficaz como treinamento muscular para ganho de força, devendo ser melhor analisada como ferramenta de condicionamento físico, por não causar riscos à saúde, ter baixo custo e ser de fácil aplicação.

Palavras-chave: Força muscular. Treinamento de resistência. Terapia por exercício.

\section{Introduction}

The proprioceptive neuromuscular facilitation (PNF), also known by the name of its founder, Herman Kabat, was developed by him, along with the American physiotherapist Margaret Knott, in the 40's. This is a kinetic therapeutic resource that uses the stimulation of proprioceptive sensibility to increase strength, flexibility and coordination, improving the quality of movement; widely used for treatment of various pathologies, facilitating the stability, mobility, neuromuscular control and coordinated movements; establishing a basis for the restoration of function (1).

The proprioceptive neuromuscular facilitation (PNF) is an approach to therapeutic exercise using specific patterns of movement in diagonal and spiral as well as afferent stimuli to promote a triggering of neuromuscular potential, getting better responses throughout the musculoskeletal system (2). The method theorizes that the motor function should be corrected by neuromuscular via through the stimulation of proprioceptors located in the joints, tendons and muscles, making use of voluntary muscle contraction; because the longer the sensory stimulation from the periphery, the larger the number of stimuli that arrive to the CNS, causing the response, accordingly, is larger (2).

PNF has been used to improve the performance and physical performance of athletes, people who are sedentary healthy and patients with organ dysfunction, especially in neuromuscular recovery (3).

The PNF techniques can be used to treat various musculoskeletal and joint disorders, injuries and diseases of the nervous system, among others, in addition to develop strength and muscular endurance. The application of PNF physical therapy techniques is 
based on the usage patterns of diagonal movements of body segments, combining movements of flexion, extension, abduction, adduction and rotation. These are patterns of movement in mass spiral and diagonal form and very similar to the movements used in sports and work activities. This type of motion is also consistent with the topographic alignment of the muscles and of structural features of the isolated muscles (4).

Most PNF techniques is developed from the knowledge of the effects of endurance. The measure of endurance applied during an activity must comply with the conditions of the patient and the objectives of the activity (5). When this occurs, there is increased muscle response to cortical stimulation and the active muscle tension, caused by the endurance, is the most effective proprioceptive facilitation (5).

Stretching techniques with PNF is characterized by the use of active muscle contraction with the purpose of causing autogenic inhibition of stretched muscle. When applied, occurs reflex muscle relaxation, associated with passive stretching, promotes an increase in the gain range of motion (6). When performing resistance exercise, as during the technical PNF, there is an increase in the contractile capacity of muscle, thus providing an increase in muscle strength (7). This prevents a more intense response of the reflex arc and, in a rhythmic repetition, regular in intensity and frequence, easily leads the receiver (muscle spindle) to adaptation and habituation (8).

For any physical activity, when it aims to increase muscle strength, there is a need to impose load for the movements, both for healthy individuals and for patients having some organ dysfunction (3). And, if applied systematically, with a certain frequency, intensity and duration, will cause adjustments in the various systems.

The increase in the size and muscle strength were associated with clinical significant improvements in walking speed, balance and functional independence (9); still training with endurance may also have substantial benefits for injuries protection in the elderly, since the falls are directly related to hip fracture, precarious balance and postural sway (9). Studies have shown a significant correlation between the bone mineral density, strength and linked muscle mass, and activities that stimulate muscle hypertrophy and strength gain seem to stimulate bone growth and associated connective tissue (10).

The PNF can also be used to improve the quality of life of people with and without pathology, increasing range of motion and gain of muscle strength, besides preventing injuries and currently has been observed its effectiveness as a physical conditioner and its ease of application, low risk to health and economy could be a useful tool in the search for good physical condition of the elderly population. Muscle hypertrophy and increased strength, along with changes in body composition and hormonal, in addition to adaptations of the nervous system associated with strength training, has a substantial impact on activities of daily living (ADLs) and functional independence of the elderly (9).

Advancing age is also associated with a reduction in muscle mass, called sarcopenia. Computed tomography shows that, after 30 years of age, there is a decrease in cross-sectional areas of individual muscles, a decrease in muscle density and increased density of intramuscular fat. These changes appear to be a predictable consequence of advancing age, more pronounced in women (10).

With appropriate force stimuli, the elderly of both sexes have similar gains in muscle strength, or even relatively superior to those found in young people. However, most of these studies on the effect of physical activity on muscle strength of the elderly is based on specific intensive training protocols of isolated functions, being less frequent studies using general physical activity programs (11).

In this sense, the present study aimed to verify and analyze possible changes in muscle conditioning after training by PNF patterns in a group of elderly. It is expected that the training brings increase of muscle strength to the group.

\section{Materials and methods}

The experiment was conducted in the Physiotherapy Laboratory, Federal University of Amazonas - Institute for Health and Biotechnology and in the Integrated Senior Center (IIC), both located in Coari (AM).

This study was conducted with women aged between 60 and 70 years, residing in the city of Coari, registered in IIC and physically active - people who practice physical activity at least three times a week with a minimum duration of 30 minutes each session (12) and clinically healthy. The choice for the female audience was due to this population is most in physical activity. 
The inclusion criteria were: being physically active; not present neuromuscular disorders or some kind of muscle change; does not have some kind of pathologies, such as diabetes, hypertension or heart diseases; and not having previously done some type of surgery of limb or lower limbs. The exclusion criteria were: not meet the inclusion criteria or not agree with the terms of the research.

Equally and randomly divided into a control group (CG) and experimental (EG) and were submitted to the analog dynamometric analysis (Dynamometer analog Crown brand, model AR200, 200 kgf capacity, produced by the Technical Oswaldo Filizola Ltd.) of the force in the Maximum Voluntary Contraction (MVC) of Quadriceps muscle of the dominant leg (for this a test was performed to identify the dominant member, which consisted of placing a ball on the floor and ask for the person to kick it, it's considered the dominant member the one that was used to kick the ball) performing hip flexion and knee extension for $5 \mathrm{~s}$.

After collection, the CG was asked to return to their normal physical activities, which are played daily in the IIC and return to the end of the experiment for new dynamometric collection. And with EG, we carried out a training program with diagonal Kabat (D1 and D2) for 3 weeks, 5 times a week, with sessions lasting 50 to 60 minutes and 5 sets of 5 repetitions for each diagonal pattern (diagonal 1 and 2 or D1 and D2), thereby performing flexion and extension in D1 and flexion and extension in D2, as shown in Figure 1.

Before starting the experiment, we held a meeting with all the participants, where the procedures performed were exposed clearly and succinctly and the benefits that the application of PNF techniques

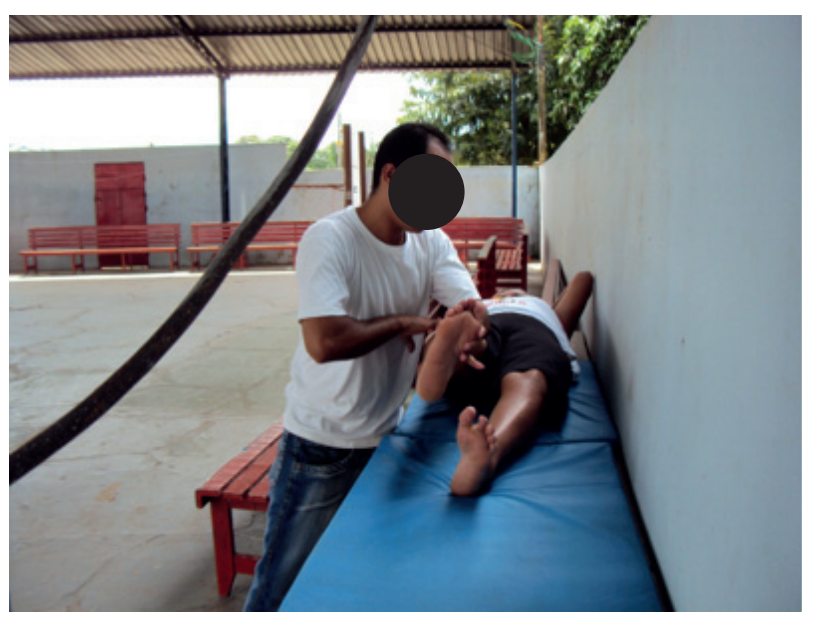

Figure 1 - FNP-based training, held at EG could bring to improving the quality of life through possible increase in muscular conditioning. The study was approved by the CEP of Amazonas Federal University as Resolution 196/96 CONEP with CAAE 0225.0.115.000-10.

After data collection, it was statistically analyzed using the GraphPad Prism 5.0 software, using the D'Agostino test for sample normality verification and two way ANOVA test to check the significance of the data.

\section{Results}

In this study, ten female subjects aged between 60 and 70 years, physically active and according to the criteria of inclusion and exclusion imposed for the procedures were studied. They were divided randomly and equally in CG and EG.

Table 1 shows the strength developed in MVC before and after the training period in the CG, while Table 2 shows the data obtained in the EG.

Table 1 - CG Muscle Strength before and after training

\begin{tabular}{crc}
\hline \multirow{2}{*}{ Subjects } & \multicolumn{2}{c}{ MVC Force (kgf) } \\
\cline { 2 - 3 } & Pre & Post \\
\hline C1 & 13 & 13 \\
C2 & 13 & 13 \\
C3 & 10.5 & 14 \\
C4 & 14 & 16 \\
C5 & 20 & 18 \\
Med & $\mathbf{1 4 . 1}$ & $\mathbf{1 4 . 8}$ \\
\hline
\end{tabular}

Table 2 - EG Muscle Strength before and after training

\begin{tabular}{crc}
\hline \multirow{2}{*}{ Subjects } & \multicolumn{2}{c}{ MVC Force (kgf) } \\
\cline { 2 - 3 } & Pre & Post \\
\hline E1 & 11.5 & 17 \\
E2 & 14 & 20 \\
E3 & 13.5 & 19 \\
E4 & 15 & 19 \\
E5 & 16 & 17 \\
Med & $\mathbf{1 4}$ & $\mathbf{1 8 . 4}$ \\
\hline
\end{tabular}


It may be noted that two subjects in the control group remained with the same muscle strength during the period (13 kgf both). Two of them showed increased strength (10.5/16 and 14/16 kgf) and one decreased strength (20/18 kgf). On average, the group achieved a $5 \%$ increase in the strength of MVC (0.7 kgf). Meanwhile, all the subjects in EG increased strength $(11.5 / 17,14 / 20,13.5 / 19,15 / 19$ and $16 / 17 \mathrm{kgf}$ ). The results showed an increase in the strength of EG, about 31\% (4.4 kgf).

After checking the normality of the data, made by D'Agostino test, was applied ANOVA test in two criteria, to analyze the results of different duration times (pre and post experiment) the CG and EG, and there was a comparison between them. After the analysis, it was found that the strength change occurred after training was significant $(p<0.01)$ as shown in Figure 2.

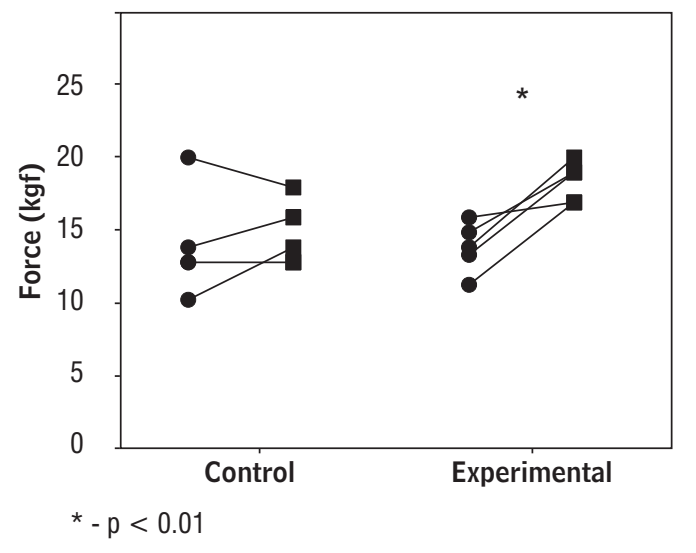

Figure 2 - Muscle strength before and after training

\section{Discussion}

The FNP is a technique widely used by physiotherapists as progressive resistance exercise alternative in search of improvement in range of motion and muscular strength gain, as well as to prevent injury and promote the rehabilitation of sports injuries. Comparing the effects of PNF and weight training, a study showed strength gains similar between the techniques, but training with PNF was more efficient in performance, evidenced by higher earnings in the modalities shoot from a distance and jump height (13).
Neuromuscular facilitation proprioceptive technique has great effectiveness if used in rehabilitation, for been a simple method, cheap, non-invasive and easy to apply (11). Taking the peculiarities of the study target region into consideration - low HDI, lack of public health services, impaired accessibility - simple application techniques and low cost, besides proved efficacy, are necessary for a realistic offer in the local rehabilitation services.

Raso et al. (14) showed that the strength produced by isometric muscle actions, concentric, eccentric, isotonic and isokinetic decreases after stopping a training program, independently of age, sex, level of fitness and associated diseases. Unequal decrease in muscle strength between young and old subjects in the 12 to 31 weeks period also suggested that there might be greater decline in muscle fiber size and greater loss of effectiveness of recruitment of motor units in the elderly subjects. The use of easy application programs, like PNF, promotes long-term maintenance preventing functional deficit - more severe - in the elderly population. In the case of the analyzed population, the application of FNP in the established periods for the meetings of subjects in the venue caused no major changes in routine for them, proving its ease of implementation in rehabilitation and recreation services.

It is possible to find an increase in strength due to neural changes on elderly, to a lesser extent than in young subjected to similar training program (15). The FNP promotes a greater increase in neural activation, and preconized that in the first two weeks of training there is an adjustment and, after this, begin to hypertrophy the fibers $(4,5)$. Strength gains an elderly engaged in a training program with weights are more related to neural adaptation than muscle hypertrophy and this adaptation can result in significant strength gains (10).

A similar survey to the one made here showed a significant increase in the average strength of an elderly group of around $22 \%$ (16). The findings of this procedure once realized showed significant increases of $31 \%$, following the expected for the type of training applied, considering the neural activation and muscle hypertrophy. In a study conducted by Kofotolis and Kellis (17) showed that four weeks of PNF exercises significantly increase lumbar spinal scale of motion and spinal muscle resistance in patients with chronic low back pain. Also suggest that short period based 
on PNF programs, dynamic or static, are particularly effective in improving the resistance and mobility of torso muscle, as well as reducing symptoms of low back pain, improving functional performance in individuals with this medical condition (17).

In a study where PNF techniques were made with the aim of developing torso muscle strength to reduce low back pain, the efficiency of the method in muscle strength training was checked, considering mainly the short application time space method, which was 4 weeks (17). This reinforces the assumption that the program applied here is viable for daily use, bearing in mind the similarity of the results, while not only the increased strength is expected in this type of training. Due to intense proprioceptive work, cortical activation, stimulation, strengthening continuous and inhibition set-enhanced muscle contraction $(6,18)$, there is a much more complex and complete work in the trained muscle tissue. Larger stretching, flexibility and reflex action are expected after training with PNF. In the elderly, strength training causes muscle hypertrophy, but modest (10-20\%) compared to the great changes that are observed in relation to the strenght (15).

In addition to the recruitment of motor units, the force that a muscle generates can be influenced by the type of contraction, the contraction speed and muscle length, also depending on the maximum voluntary muscle activation, in other words, the increased recruitment of motor units at a shooting frequency $(10,19)$.

The decreased muscle strength results in reduced levels of strength associated with lower walking speed and inbalance, causing increased risk of falls and fractures in the elderly. In general, progressive losses of strength tend to make the elderly unable to accomplish the basics tasks of day-to-day, reducing their quality of life (20).

On the other hand, the strength can be improved in the elderly, since they subject a training program with overloads. Silva and Farinati (20) reinforce this possibility, showing gains in muscle function and structure, joint and bone with similar training, explaining the considerable increase of strength training programs focus in this population. The findings of this study corroborate the above statement, showing that the implementation of this training program as a constant for the target population is adequate. An important point to consider was the small sample $n$, which can generate questions about the validity of the results. Even the findings here are consistent with similar methodology research and present consistent results, it is suggested that new interventions in groups with a larger sample size are made to resolve any doubts.

\section{Conclusion}

The training based on the PNF was efficient to provide significant gains in muscle strength after 15 sessions for the population studied. Presume that this result is a consequence of the physiological effects of the technique, which develops the muscle fiber fitness for a correction efficiency in the neural activation and then the fiber hypertrophy. The characteristics of the PNF - easy application, low cost and low risk to health - show that this is an important method to consider in training programs for the elderly population in general, including in preventive public programs. We suggest the replication of this protocol in larger, multi-regional samples, in order to map the findings and reference them in a national index.

\section{Acknowledges}

The Elderly Community Center and his professional team who spared no efforts in the necessary assistance to carry this work out.

\section{References}

1. Kisner C, Lynn AC. Exercícios terapêuticos: fundamentos e Técnicas. 4. ed. Barueri: Manole; 2005.

2. Cruz-Machado SS, Cardoso AP, Silva SB. O uso do princípio de irradiação da facilitação neuromuscular proprioceptiva em programas de reabilitação: uma revisão. In: Anais do 11. Encontro Latino Americano de Iniciação Científica e 7. Encontro Latino Americano de Pós-Graduação; 18-19 out 2007; São José dos Campos, SP, Brasil. São José dos Campos: Universidade do Vale do Paraíba; 2007.

3. Moreno MA, Silva E, Gonçalves M. 0 efeito das técnicas de facilitação neuromuscular proprioceptiva - método Kabat - nas pressões respiratórias máximas. Fisioter Mov. 2005;18(2):53-61. 
4. Voss DE, Ionta MK, Myers BJ. Facilitação neuromuscular proprioceptiva. 3. ed. São Paulo: Panamericana; 1987.

5. Adler SS, Beckers D, Buck M. Facilitação neuromuscular proprioceptiva. 2. ed. São Paulo: Manole; 1999.

6. Gama ZAS, Medeiros CAS, Dantas AVR, Souza TO. A influência da frequência de alongamento utilizando facilitação neuromuscular proprioceptiva na flexibilidade dos músculos isquiotibiais. Rev Bras Med Esporte. 2007;13(1):33-8.

7. Tamburus NY, Facirolli K, Grassi DO, Moreno MA. A influência das técnicas de facilitação neuromuscular proprioceptiva sobre as pressões respiratórias de homens sedentários. In: Anais do 7. Congresso de Pós-Graduação; 2009; Piracicaba, SP, Brasil. Piracicaba: Unimep; 2007.

8. Bello M. Aplicação da técnica de estabilização rítmica em membros inferiores para prevenção de lesões musculoesqueléticas em atletas de futsal [dissertação]. São Paulo: Universidade São Judas Tadeu; 2005.

9. Guccione AA. Fisioterapia geriátrica. 2. ed. Rio de janeiro: Guanabara Koogam; 1993.

10. Simão R. Fisiologia e prescrição de exercícios para grupos especiais. 2. ed. Rio de janeiro: Phorte; 2007.

11. Carvalho LC, Marinho LF, Ferreira JJA, Guedes DT. Eletromiograma superficial na avaliação da função muscular de pacientes hemiparéticos sob tratamento fisioterapêutico. In: Memorias de lo 2. Congreso Latinamericano de Ingeniería Biomédica; 2001; Habana, Cuba. Habana: CLAB; 2001. Artículo 122.

12. Powers SK, Howley ET. Fisiologia do exercício. 5. ed. Barueri: Manole; 2005.

13. Kofotolis N, Vrabas IS, Vamvakoudis E, Papanikolaou A, Mandroukas K. Proprioceptive neuromuscular facilitation training induced alterations in muscle fibre type and crosssectional area. Br J Sports Med. 2005;39(3):e11.
14. Raso V, Matsudo SMM, Matsudo VKR. A força muscular de mulheres idosas decresce principalmente após oito semanas de interrupção de um programa de exercícios com pesos livres. Rev Bras Med Esporte. 2001;7(6):177-86.

15. Tortuga MP, Ambrosini AB, Mello A, Severo CR. Treinamento de força para idosos: uma perspectiva de trabalho multidisciplinar.. Revista Digital (Buenos Aires). 2005 [cited 2015, May 29];10(82). Available from: http://www.efdeportes.com/efd82/treinam.htm

16. Pin AS, Ramos JS. Avaliação dinamométrica digital da força do m. quadríceps de idosas antes e após treinamento com método kabat de FNP. In: Anais do 18. Congresso Brasileiro de Fisioterapia; out 2009; Rio de Janeiro, RJ, Brasil. Rio de Janeiro: Crefito, 2009.

17. Kofotolis N, Kellis E. Effects of two 4-week proprioceptive neuromuscular facilitation programs on muscle endurance, flexibility, and functional performance in women with chronic low back pain. Phys Ther. 2006;86(7):1001-12.

18. Orsini M, de Freitas MRG, Oliveira ASB, Silva JG, Leite MA, Nascimento OJM. Efectos de un programa de facilitación neuromuscular propioceptiva sobre la amiotrofia focal benigna. Rev Neur. 2010,51(5):317-8

19. Oliveira AS, Tucci HT, Verri ED, Vitti M, Regalo SCH. Influência da posição do braço na relação EMG-força em músculos do braço. Fisioter Pesqui. 2008:15(3):221.

20. Silva NL, Farinatti PTV. Influência de variáveis do treinamento contra-resistência sobre a força muscular de idosos: uma revisão sistemática com ênfase nas relações dose-resposta. Rev Bras Med Esporte. 2007;13(1):60-6.

Received: $10 / 08 / 2013$

Recebido: 08/10/2013

Approved: 02/27/2015

Aprovado: 27/02/2015 